W zakończeniu (recenzowanej publikacji) pt. „Zamiast zakończenia... czyli o warunkach i niektórych rezultatach socjalizacji przebiegającej w warunkach konfliktu ideowo-politycznego w latach PRL-u” Romuald Grzybowski sformułował kilka wniosków z przeprowadzonych badań naukowych; dotyczą one głównie efektów procesu socjalizacji Polaków w państwie totalitarnym. Należy dodać, że książka Profesora Romualda Grzybowskiego jest bardzo dobrze udokumentowana, a oprócz przypisów dokumentacyjnych implikuje również przypisy dopowiadające, polemiczne, słownikowe. Z pewnością może służyć również cenną pomocą dydaktyczną w lepszym zrozumieniu warunków kształtowania wszystkich kategorii postaw w społeczeństwie polskim w okresie PRL-u, zwłaszcza ideowych, szeroko pojętego dziedzictwa edukacyjnego Polskiej Rzeczpospolitej Ludowej. Tym bardziej, że historia Polski z lat 1945-1989 jest słabo znana wśród studentów, co ujawniają badania naukowe, które Autor przytacza we wprowadzeniu do niniejszej publikacji.

Edyta Wolter

\title{
Piotr Gołdyn, Stawomir Czerwiński (1885-1931). Minister oświaty, przyjaciel Kalisza, Kalisz 2013, ss. 88
}

Praca zatytułowana Stawomir Czerwiński (1885-1931). Minister oświaty, przyjaciel Kalisza ukazała się jako szósty tom w serii „Kaliszanie” nakładem Kaliskiego Towarzystwa Przyjaciół Nauk. Autorem tej publikacji jest Piotr Gołdyn ${ }^{1}$. Seria ta kontynuuje prezentację zasłużonych mieszkańców tego miasta. Nie tylko tych rodowitych, lecz także „kaliszan z wyboru”, przybyłych w związku z edukacją lub pracą, a których dokonania są także warte przypomnienia.

Jako ważny powód popularyzacji życia i działalności S. Czerwińskiego - wybitnego pedagoga, późniejszego Ministra Wyznań Religijnych i Oświecenia Publicznego w II Rzeczypospolitej Polskiej, twórcy Instytutu Nauczycielskiego w Warszawie - Autor podaje lukę w panteonie znaczących postaci związanych z II RP. W opinii Autora może to być spowodowane przedwczesną śmiercią ministra, odejściem Józefa Piłsudskiego od modelu wychowania państwowego, rządami komunistycznmi oraz niechęcią do sanacji.

1 Piotr Gołdyn jest doktorem nauk humanistycznych, historykiem oraz regionalistą. Studiował na Papieskim Wydziale Teologicznym w Warszawie. W roku 2002 obronił rozprawę doktorską na Uniwersytecie Zielonogórskim. Jest także członkiem zarządu Kaliskiego Towarzystwa Przyjaciół Nauk oraz członkiem Towarzystwa Historii Edukacji. Współpracuje ze Związkiem Polaków w Rumunii. Jest autorem i redaktorem kilkunastu książek oraz ponad dwustu artykułów naukowych, popularnonaukowych i popularnych. M.in.: Symbolika religijna i kościelna $w$ herbach miast polskich do końca XX wieku, Warszawa 2008; Z pól do wolności. Szkic do dziejów opozycji wiejskiej na ziemi konińskiej (1980-1989), Konin 2009; Trud i chwała strażaka. Dzieje Ochotniczej Straży Pożarnej w Lądku w latach 1908-2008, t. I, Lądek 2009; Protestantyzm w Polsce na przestrzeni wieków, Poznań 2009; II wojna światowa w Wielkopolsce Wschodniej. Wybrane aspekty, Konin 2010; Religia w procesie resocjalizacji, Konin 2010; Dzieje Sompolna, t. I, Wiek XX, Sompolno 2011; Diamentowa książnica. Sześćdziesiąt lat Publicznej Biblioteki Pedagogicznej w Koninie, Konin 2012. 
Publikacja P. Gołdyna jest pierwszą tego typu próbą zaprezentowania życia i bogatej działalności ministra S. Czerwińskiego.

Książka sklada się ze „Wstępu” (s. 7-8), w którym Autor uzasadnia swą próbę przedstawienia zasług S. Czerwińskiego dla polskiej oświaty, pięciu rozdziałów, zakończenia, wykazu literatury oraz spisu ilustracji. Rozdział pierwszy pt. „Rodzina, wykształcenie, praca" (s. 9-27) ukazuje środowisko rodzinne oraz drogę edukacyjną przyszłego ministra. Począwszy od nauki w kaliskim Męskim Gimnazjum Klasycznym aż po studia uniwersyteckie. Autor omawia także aktywność S. Czerwińskiego na rzecz polskiej szkoły - udział w wiecach, akcjach strajkowych, kompletach podczas których starsi uczniowie uczyli swych młodszych kolegów. Przybliża także udział w pracach Narodowego Związku Robotniczego.Przybliża koleje losu po usunięciu z kaliskiego gimnazjum i przeniesienie do Krakowa, gdzie S. Czerwiński podjął studia na Uniwersyetcie Jagiellońskim (w zakresie historii literatury polskiej pod kierunkiem prof. Ignacego Chrzanowskiego oraz w zakresie gramatyki historyczno-porównawczej języka polskiego u prof. Jana Łosia). P. Gołdyn w swej pracy przedstawia też jego zaangażowanie w działalność Towarzystwa Wzajemnej Pomocy Kaliszan, Związku Młodzieży Polskiej - „Zetu” oraz „Zarzewia”. W tej części pracy odnaleźć można także informacje na temat jego pracy w Centralnym Biurze Szkolnym, kierowanym przez Ksawerego Praussa. To także czas jego aktywności jako dyrektora szkoły w Ostrowcu Świętokrzyskim, przewodnictwa w Kole Towarzystwa Nauczycieli Szkół Wyższych w Piotrkowie Trybunalskim oraz prac w Stowarzyszeniu Nauczycieli Szkół Średnich w Ostrowcu. Dalsza jego droga zawodowa to przede wszystkim stanowisko starszego referenta w MWRiOP, następnie posada radcy ministerialnego, wizytatora seminariów nauczycielskich aż do objęcia obowiązków podsekretarza stanu.

W rozdziale drugim pt. „Działalność w ministerstwie” (s. 28-51) Autor prezentuje działalność S. Czerwińskiego na stanowisku ministra Wyznań Religijnych i Oświecenia Publicznego, od 1929 r. aż do jego nagłej śmierci w 1931 r. Były to czasy rządów kolejno: Kazimierza Świtalskiego, Kazimierza Bartla, Walerego Sławka (dwukrotnie), Józefa Piłsudskiego oraz Aleksandra Prystora. Kolejny rodział, trzeci pt. „Troska o polską szkołę" (s. 52-66) to próba ukazania zasług ministra na rzecz polskiej oświaty. Jak stwierdza P. Gołdyn, S. Czerwiński troskę o polską szkołę wyraził w swych przemównieniach oraz wystąpieniach publicznych, które po śmierci ministra zostały zebrane i wydane w pracy pt. O nowy ideat wychowawczy. Zdaniem Autora S. Czerwiński troskę też przejawiał, wprowadzając w polskich szkołach ideologię wychowania państwowego. Dla udowodnienia tej tezy przytacza też idee zawarte w wystąpieniu ministra pt. O ideat wychowawczy szkoły polskiej wygłoszonym w roku 1929. Ideologia ta stała się więc motywem przewodnim większości jego wystąpień. Kolejnym, zdaniem Autora, ważnym przejawem troski o polską oświatę było zainteresowanie się S. Czerwińskiego polskim nauczycielem i polskim uczniem. Dawał temu wyraz także w swoich wystąpieniach, przemówieniach radiowych czy spotykając się z dyrektorami szkół itp. Był również obecny na kongresach, zjazdach i innych spotkaniach o charakterze oświatowym.

W kolejnym rozdziale pt. „Kontrowersje wokół śmierci i pogrzebu” (s. 67-77) P. Gołdyn porusza kwestię nagłej śmierci ministra S. Czerwińskiego oraz kontrowersji z nią 
związanych. Chodziło mianowicie o to, że S. Czerwińskiego - ewangelika pochowano w obrządku rzymsko-katolickim. Śmierć tego zasłużonego pedagoga i działacza zaskoczyła nie tylko środowisko oświatowe, ale i znaczą część społeczeństwa polskiego.

W ostatnim, piątym rozdziale pt. „Przejawy pamięci” (s. 78-80) Autor podaje, że jednym z pierwszych przejawów pamięci było uhonorowanie S. Czerwińskiego przez prezydenta Ignacego Mościckiego Wielką Wstęgą Orderu Odrodzenia Polski - za wybitne zasługi dla oświaty. Pamięć ministra została także uczczona podczas posiedzenia sejmu w 1931 r. Imię S. Czerwińskiego noszą także ulice, np. w Ostrowcu Świętokrzyskim oraz kilka szkół w Polsce (np. Szkoła Podstawowa nr 11 w Kaliszu). W 1932 r. Polska Marynarka Wojenna także nadała okrętowi imię ORP „Sławomir Czerwiński”.

Jak stwierdza sam Autor w „Zakończeniu” (s. 81-82) praca nie wyczerpuje całości wiedzy na temat ministra S. Czerwińskiego, a jest jedynie pewnym zasygnalizowaniem tematów zasługujących na zgłębienie. Na szczególną uwagę zasługuje fakt, że Autor w swej publikacji zgromadził wiele fotografii pochodzących ze zbiorów: Archiwum Państwowego w Krakowie, Archiwum Uniwersytetu Jagiellońskiego w Krakowie, Narodowego Archiwum Cyfrowego, Stowarzyszenia Wychowanków Gimnazjum i Liceum im. Asnyka w Kaliszu, Kaliskiego Towarzystwa Przyjaciół Nauk, Biblioteki Sejmowej w Warszawie, Książnicy Pedagogicznej im. A. Parczewskiego w Kaliszu, a także publikowanych na łamach „Cyrulika Warszawskiego”, znajdujących się w prywatnych zbiorach i witrynach internetowych. Oddana do rąk czytelnika książka jest formą oddania hołdu zasłużonemu ministrowi - S. Czerwińskiemu i jego pracy na rzecz polskiej oświaty. Spełnia także funkcje popularyzacji wiedzy o zasłużonych Polakach lat międzywojennych pracujących na rzecz oświaty polskiej.

Joanna Falkowska

\section{Wychowanie $w$ rodzinie. Przekaz tradycji i kultury na przestrzeni wieków, tom 1, red. S. Walasek, L. Albański, Wydawnictwo: Karkonoska Państwowa Szkoła Wyższa w Jeleniej Górze, Jelenia Góra 2011, ss. 276}

Historycy wychowania Instytutu Pedagogiki Uniwersytetu Wrocławskiego oraz pedagodzy Wydziału Humanistycznego Karkonoskiej Państwowej Szkoły Wyższej w Jeleniej Górze powołali serię wydawniczą pod tytułem „Wychowanie w rodzinie”. Jej ideą jest stworzenie interdyscyplinarnej płaszczyzny do wymiany poglądów, prezentowania wyników badań, proponowania praktycznych rozwiązań problemów dotyczących rodziny. Inicjatorzy serii pragną więc, na łamach kolejnych tomów, zaprezentować wielowymiarowy obraz rodziny, „malowany” przez reprezentantów różnych dyscyplin naukowych, z krajowych i zagranicznych ośrodków naukowych.

Pierwszy tom wspomnianej serii stanowi, wydana w roku 2011, praca Wychowanie w rodzinie. Przekaz tradycji i kultury na przestrzeni wieków pod redakcją Stefanii Wala- 